\title{
PUBLIC PERCEPTION OF THE CONSEQUENCES OF POVERTY IN SELECTED LIFE DIMENSIONS
}

\author{
Nadežda Kovalčíková ${ }^{1}$, Andrea Bánovčinová ${ }^{2}$
}

\begin{abstract}
Poverty is a phenomenon that receives a lot of attention from a wide range of professionals as well as the lay public. This is a serious problem that significantly changes the lives and functions of individuals, families, as well as communities.

The aim of this study was to find out how society perceives the consequences of poverty in individual dimensions of human life selected by us and also to find differences in perception of the consequences of poverty in terms of the selected demographic data (gender, place where the respondent lives, place of residence - city or countryside, faith, employment status, shared household, benefits in material deprivation, and an opinion on who should primarily address the problem of poverty). A quantitative research strategy was implemented using a self-designed questionnaire. The questionnaire contained 37 items and focused on the perception of poverty and its consequences in our selected areas. The questionnaire contained 6 basic dimensions, resp. areas. These were the health area, the hygiene area, the social area, the psychological area, the structural area and the housing area. We used a deliberate and quota selection (region, gender). The total sample (n) consisted of 384 respondents. The average age of the respondents was $36.30 \pm 12.91$ years old (min. 18, max. 75).

The results did not show a statistically significant difference in the perception of areas most affected by poverty in terms of gender; in terms of receiving benefits in material need, there was a statistically significant difference in health, mental health, housing and social affairs. In terms of residence (countryside, city), a statistical difference was recorded only in the area of health. There were also significant statistical differences in the area of geography (the region in which the respondent lives), in the area of health and hygiene, and the structural area. The practice of faith has proven to be an important determinant of the perception of poverty, especially in the social and psychological spheres. We also noticed differences in the perception of poverty in some areas in terms of shared household and employment status.
\end{abstract}

UDC Classification: 304, DOI: https://doi.org/10.12955/pss.v2.222

Keywords: Poverty. Consequences. Public. Perception.

\section{Introduction}

Poverty is a complex and challenging area of interest and is currently still one of the major challenges of the globalised world. For many years Slovakia is one of the countries with the lowest income inequalities, but there is a slight increase in the Gini index since the 1990s (Laca, 2011; Botek, 2019). Poverty is one of the most observed socio-economic phenomena in Slovakia, and its range and social consequences increase (Michálek, 2000), in spite of poverty indicators in Slovakia remaining lower than the EU average, except for severe material deprivation (Botek, 2019). These facts result in intensive poverty research in Slovakia. The focus of this research varies. Some focus on the causes and consequences of poverty towards individuals and families, others on coping strategies or satisfying one's basic needs. A lot of the research focuses on public attitudes and public perceptions of the causes and consequences of poverty rather than the direct impacts of poverty. Public perception of the causes of poverty (why people became poor) is part of the collective perception of poverty. It is an important element by some authors (Pakosta \& Rabušic, 2010) because social assistance tools are based on the solidarity principle followed by redistribution, and if the community does not feel poor people deserve assistance, they will not support these programs and tools. The public's views on the poor and the reasons for poverty provide important insights into the legitimacy of collective responses to it in the form of institutionalized welfare systems and anti-poverty policies (Strapcová, 2004). The aim of the study is to find out how society perceives the consequences of poverty of an individual in selected dimensions of a person's life, as well as to identify differences in the perception of the consequences of poverty in terms of selected demographic data: gender, place where the respondent lives (the region in which the respondent lives) place of residence (city, countryside), faith, employment status, shared household, benefits in material deprivation and an opinion on who should primarily address the problem of poverty.

\section{Methodology and respondents}

We used a quantitative research strategy using two questionnaires to meet the goals. The first of the questionnaires focused on the perception of the consequences of poverty. In its compilation, we were inspired by a questionnaire created by Stacey and Singer (1985). In their questionnaire the authors

\footnotetext{
${ }^{1}$ Faculty of Health Care and Social Work of Trnava University in Trnava, Slovakia, nadezda.kovalcikova@truni.sk

${ }^{2}$ Faculty of Health Care and Social Work of Trnava University in Trnava, Slovakia, andrea.banovcinova@truni.sk
} 
addressed issues related to the psychological and social dimension. In addition to these two areas, we added health, appearance, housing and structural areas to our questionnaire. The questions in the questionnaire were thus grouped into 6 dimensions of the consequences of poverty, namely health, physical (appearance), social, psychological, structural and housing conditions. Respondents within each dimension should have given a degree of consent to individual statements. An example of a statement in the health dimension is: Poor people are those who cannot afford a quality diet, tend to be more often ill, suffer from addictions (alcohol, drugs, etc...). The second questionnaire consists of questions focused on demographic data. We used a deliberate and quota selection (region, gender) The total sample (n) consisted of 384 respondents. The average age of the respondents was $36.30 \pm 12.91$ years old (min. 18, max. 75). We also included respondents' faith among demographic indicators. In the Trnava region, the answer "yes, I practice faith" was answered by 47 (29.1\%) respondents. "Yes, I am a believer, but I do not practice faith" was answered by 77 respondents $(47.8 \%)$ and those who do not practice faith were 37 (22.9\%) in number. In the Prešov region, 79 respondents (35.4\%) are believers but do not regularly practice faith. Conversely, 89 respondents $(39.9 \%)$ are believers and actively practice faith. 55 respondents $(24.7 \%)$ are non-believers. We were also interested in whether the respondents were receiving a benefit in material need. The results showed that out of 223 respondents, only 55 respondents $(24.7 \%)$ received a benefit in material need. while $167(75.2 \%)$ respondents did not receive this benefit, as data shown in the Prešov region. In the Trnava region, 37 respondents (22.9\%) received the benefit, and $124(77.0 \%)$ respondents did not receive the benefit. Within the demographic data, regarding employment status, in the Trnava region, 39 respondents $(24.2 \%)$ were unemployed, 14 respondents $(8.6 \%)$ had a part-time job and $78(48.4 \%)$ were full-time workers. 9 respondents $(5.59 \%)$ receive an invalidity pension and 21 respondents $(13.0 \%)$ receive an old-age pension. There are 58 respondents $(26 \%)$ unemployed, $32(14.2 \%)$ part-time workers and $100(44.2 \%)$ full-time workers in the Prešov region. Furthermore, $19(8.5 \%)$ of the respondents are disabled pensioners and 14 of those surveyed are old-age pensioners $(6.2 \%)$.

\section{Results and discussion}

The main aim of our study is to find out the public perception of the consequences of poverty in the above defined dimensions in two regions of Slovakia. Citizens are social policy actors, as well as those, who receive social assistance. Their perception of poverty does not only affect their perception and behaviour towards the poor, but also their preference for political parties and movements, often radically. That is why research in this area is very important and we decided to focus on the perception of the consequences of poverty in our research.

We present the main research findings in the interpretation of data and discussion section. Analysis of the average score of individual dimensions showed significant differences in terms of both regions. There was no consensus between the regions we examined in either dimension. The highest average score achieved in the Trnava region was 3.54 in the physical dimension. Respondents in the Trnava region perceive physical appearance as the greatest consequence of poverty. According to them, poor is the one who has, for example, weak hygiene habits and is dirty, is not physically attractive, does not care about his appearance and wears inappropriate clothes (worn, inappropriate size, etc.). Respondents within the Prešov region achieved a top score of 3.33 in the Housing problems dimension. In their view, the impact of poverty is therefore most noticeable in the area of housing and is linked, for example, to the impossibility of having their own place to live, or the need for housing in marginal parts of towns or villages. They also see poor quality of housing as a consequence of poverty. Michálek (2004) also notes that an important indicator of low living standards, material deprivation and poverty is also insufficient, low housing. The result is interesting. In our opinion, this is influenced by the fact that respondents from the Prešov region are confronted with poverty at a higher rate and therefore seem to have a more realistic picture of the consequences of poverty than respondents of the Trnava region.

The area on which poverty has the lowest impact by our respondents is the social dimension. Respondents from both counties agreed on this answer. We were surprised by this result, as it is precisely this dimension that includes, for example, statements that poverty has an impact on crime, is also associated with insufficient and poor education of children, and that the poor live in families that are confronted with problems, etc. Thus, poverty is least associated with the concepts of pathology, troubled family, etc. to respondents. As Ondrejkovič (2009) notes, poverty in itself does not significantly affect the development and functioning of society. However, its effect creates a number of secondary deviances 
and psychopathological phenomena that seriously threaten society. These include, for example, gambling, unemployment, homelessness, crime and various types of addiction.

Other results show differences in the perception of the impacts of poverty according to our selected demographic data. We have noticed differences in almost all demographic factors except gender. As part of the interpretation, we will mention demographic factors where we have noted the existence of differences in the perception of the consequences of poverty in several areas.

In tackling poverty, the state has set a subsistence minimum. For those with a monthly income below a specified level of this minimum, it shall contribute, within the framework of social assistance, to the relevant benefits in material need (Demek, 2011). The use of benefits in material need refers to a standard of living which is significantly distant from the standard of the whole population (Gerbery \& Džambazovič, 2017). The use of benefits in material need as an indicator of poverty has been shown to be the most important factor determining the perception of the consequences of poverty. As part of the results, we found significant differences in the largest number of dimensions - Health $(p=0.000)$, Housing $(\mathrm{p}=0.000)$, Social $(\mathrm{p}=0.031)$ and Psychological area $(\mathrm{p}=0.042)$. An interesting fact was that it was the beneficiaries of material need allowances who had the lowest average scores in health and housing, so they perceived these areas as the least affected by poverty. We were surprised by this result, as objective material deprivation is often mentioned in relation to poverty, which is linked, for example, to housing conditions and the availability of services, or to low levels of needs (Želinský, 2014). According to the author, persons can be considered poor if they have a lack of resources to procure such forms of food, clothing, good working and educational conditions, but also are unable to participate in activities that are customary for the society to which they belong or are generally accepted in the society. However, in relation to the above-mentioned facts, it should be noted that in recipients of material need benefits, we also recorded higher scores in the structural area. Low income (below the subsistence minimum) limits them in access to services, quality education, etc., which, according to the author, is one of the consequences of poverty. Conversely, respondents who are not beneficiaries showed the least positive responses in this dimension.

Another variable where we noticed differences in several areas was the respondents' opinion on who should tackle poverty. According to the respondents, it should be overwhelmingly the state. The state considers the reduction of poverty and social exclusion to be a long-term priority of public policy in Slovakia (Ministerstvo práce, sociálnych vecí a rodiny, 2021). Social policy on poverty reduction has traditionally rested on two major pillars: financial benefits and social services. These are complemented by various measures in the area of the education system and the labour market, aimed at both addressing current problems, preventive action and at eliminating conditions creating risks of poverty later in life (Gerbery et al., 2007). Poverty reduction is therefore a multidimensional phenomenon with participation of both governmental and non-governmental actors. Up to 139 respondents (62.33\%) in the Prešov region identified the option "State", while in the Trnava region it was 111 respondents (68.94\%). The possibility that poverty is to be addressed by the poor themselves was identified by 55 respondents in the Prešov region $(24.66 \%)$ and 38 respondents $(23.60 \%)$ in the Trnava region. 18 respondents from the Prešov region $(8.07 \%)$ identified that the problem of poverty is to be solved by charity, the third sector. Only 7 respondents $(4.34 \%)$ scored this possibility in the Trnava region. In the Prešov region, 11 respondents $(4.93 \%)$ stated that the problem should be solved by the municipality/city and $5(3.10 \%)$ stated this in the Trnava region. As we mentioned above, we have also recorded statistically significant results in terms of who should tackle the problem of poverty and the perceived consequences of poverty in individual dimensions. These were differences in the health dimension $(p=0.000)$, structural dimension $(\mathrm{p}=0.000)$ and housing area $(\mathrm{p}=0.026)$. According to respondents, the impact of poverty on all three areas mentioned above should mainly be addressed by the state. They see the aid of municipalities and towns as the least beneficial in addressing health impacts. However, municipalities and towns are in second place in the field of dealing with impacts on the structural area. An interesting result was that, according to the respondents, in dealing with the impact of poverty on housing, the poor themselves should deal with this area after the state. Individual responsibility also dominated the field of physical appearance. According to respondents, the non-governmental sector plays the most important role in addressing the consequences on the field of appearance and psyche.

In other results, we noted significant statistical differences in the area of geography (the region in which the respondent resides) in the areas of health $(\mathrm{p}=0.003)$, appearance $(\mathrm{p}=0.000)$ and structural area $(\mathrm{p}=$ 
0.001), with the highest score and thus the highest consent rate across all three dimensions, recorded among respondents in the Trnava region with the highest level of consent in the item "appearance". Respondents from the Prešov region agreed to this possibility the least. With the fact that the consequences of poverty are mainly in the structural area, we found the second smallest level of consent in the Prešov region compared to other dimensions. The structural area contains statements that poor people have less access to quality education, services, are reliant on the help of others and can only afford low-paid work. They have to spend a lot of time in employment and therefore there is no meaningful leisure time for them. Another interesting fact was that respondents from the Prešov region perceive the psychological dimension as the area most affected by poverty, that "connected" the poor with the concepts of low self-esteem, fear, etc.

The way of living or co-living in the household with other members is another factor that affects the perception of the consequences of poverty. We noticed significant differences mainly in the structural dimension $(\mathrm{p}=0.048)$ and in the housing dimension $(\mathrm{p}=0.034)$, with the highest scores and thus the highest consent rate recorded within these two dimensions among respondents who live alone. These respondents perceive the consequences of poverty mainly through the impossibility of securing suitable housing and also through the impossibility of accessing quality education. They also perceive the consequence of poverty in the context of benefit and the impossibility of changing this situation without external assistance. This result is likely to be influenced by the facts highlighted by Rabušicová et al. (2012); according to the authors, the composition and structure of the family affects the life of individual members, especially their chances of getting family support the moment they need it. Co-sharing of a multi-member household is a source of solidarity, and, for example, functional solidarity is a level of assistance and exchange of resources, an assessment of reciprocity in intergenerational exchange of resources, whether parents and children are helping each other. It's mostly about financial, mental, emotional assistance. More concretely, these include, for example, donating funds (e.g. buying food, medicines), helping with household chores, or helping with the care of a family member (Levická et al., 2015). In single-member households, this mutual assistance is at a minimal, or may be totally absent, which is why, for example, the consequences of poverty are also perceived most intensively in the aforementioned areas. In multi-member households, the possibilities for assistance and support are much broader.

Employment status changes the perceptions of the consequences of poverty as well, but only in the structural $\mathrm{p}=0.021$ dimension and in the housing dimension $(\mathrm{p}=0.006)$. In the structural area, we recorded the highest scores in the employment status of old-age pensioners. They most agreed with the fact that poverty mainly changes the area of access to resources, they also perceive the impact of poverty through social benefits. The second highest score was found for the unemployed respondents. Their perception of the impact of poverty in this area is probably determined by their current situation, which has significantly reduced their income. The perception of the impact of poverty mainly through the area of housing from the point of view of employment status was recorded in the results mainly for those in full-time employment, the smallest score was for old-age pensioners and the unemployed.

The place of housing (city, countryside) is an important factor that can determine the perception of the consequences of poverty. However, we recorded a statistically significant difference only in the health dimension $(p=0.048)$ in our results. Within this dimension, we found a higher level of consent among rural respondents. This result may be influenced by the fact that rural citizens generally have less access to services and, for example, access to healthcare is often conditioned by traveling to a health facility in the city, which certainly causes higher expenditure. The poverty factor itself will further exacerbate these problems. Self-care, access to quality food and access to healthcare are areas that are strongly affected by low income even according to other research findings. Income has an obvious impact on health, since it provides means for the prerequisites for good health (shelter, food, heat, etc.). Low income increases an individual's exposure to harmful environments, as well as reduces the family's ability to meet essential needs such as a healthy diet (Šipikalová, 2014). The author also highlights the fact that poverty also increase harmful behaviours. Respondents also agreed to a more frequent presence of addictions in poor families within this dimension.

Faith has also proven to be a predictor of perception of the consequences of poverty. The results showed significant differences in two areas - psychological $(\mathrm{p}=0.024)$ and social $(\mathrm{p}=0.020)$. The highest average score in these two dimensions, and thus the highest level of consent, was recorded in non- 
practicing believers. They see a poor person as someone who fears the future and doesn't have possibilities to fulfil his dreams. They agreed that the poor person is modest and has low self-esteem. Within the social dimension, they more agree that the poor are those who live in troubled families and commit crimes. We found the highest rate of consent responses among practicing believers in the structural dimension and appearance. Thus, practicing believers perceive the consequences of poverty as if through a "classic" perception of poverty as such. Poor is the one who does not have enough or suitable clothes, has a neglected their appearance, has minimal access to services, is also reliant on benefits and is unable to deal with their situation without the help of others.

\section{Conclusion}

The study focused on the perception of the poverty consequences on different life areas by the Slovak public. We found that this perception varies in terms of different demographic variables. The factor in which we noticed differences in up to four life areas is the personal experience of poverty. In the opinion of the respondents who receive and do not receive benefits in material need, we noticed the most significant differences in their perception of poverty consequences on individual life areas. Another variable that changed the perception of poverty consequences is the opinion of respondents on who should address the impacts of poverty in individual areas as a matter of priority. We have identified significant differences in three areas. As the third factor, where we noticed differences in perception of consequences in up to three areas, was the respondents' geographical residence. Gender is the only variable where we have not seen any significant differences.

\section{Acknowledgement}

This paper was prepared as a part of the project Working Poverty [VEGA 1/0322/18] funded by The Scientific grant agency of The Ministry of Education, Science, Research and Sport of the Slovak Republic and Slovak Academy of Sciences.

\section{References}

Botek, O. (2019). The Slovak welfare system : from turbulent times to stability. In: Schubert, K., Blum, S., \& Kuhlmann, J. (Eds.). (2019). Routledge Handbook of European Welfare Systems (2nd ed.). Routledge.

https://doi.org/10.4324/9780429290510

Demek, P. (2011). Chudoba, hmotná núdza, nepriaznivá sociálna situácia a krízová sociálna situácia ako predmet záujmu práva sociálneho zabezpečenia a súvisiace právne aspekty. Rizikové súvislosti chudoby a rodiny v súčasnej slovenskej spoločnosti [Poverty, material deprivation, unfavorable social situation and crisis social situation as a subject of interest of social security law and related legal aspects. Risk links between poverty and family in contemporary Slovak society], 38-49

Gerbery, D., Lesay, I., \& Škobla, D. (2007). Kniha o chudobe. Spoločenské súvislosti a verejné politiky. [A book on poverty ]. Social context and public policies. Priatelia Zeme-CEPA, FES Bratislava.

Gerbery, D. \& Džambazovič, R. (2017). Urbánna chudoba na Slovensku. [Urban poverty in Slovakia] Geografický Časopis [Geographical Journal] 69 (3), 263-280 https://www.sav.sk/journals/uploads/10241251Gerbery,\%20D\%C5\%BEambazovi\%C4\%8D.pdf

Laca, S. Súčasné aspekty chudoby v Slovenskej spoločnosti. Rizikové súvislosti chudoby a rodiny v súčasnej slovenskej spoločnosti, [At the same time aspects of poverty in Slovak society. Risk links between poverty and family in contemporary Slovak society ], $30-37$

Levická, J., Levická, K. \& Truhlářová, Z. (2015). Teoreticko - empirické reflexe solidarity. [Theoretical - empirical reflections on solidarity] Hradec Králové: Gaudeamus.

Michálek, A. (2000). Chudoba, jej koncepty a geografické dimenzie. [Poverty, its concepts and geographical] dimensions] Geografický časopis [Geographical Journal] 52(3), 231 - 242

Michálek, A. (2004). Chudoba na lokálnej úrovni (Centrá chudoby na Slovensku) [Poverty at the local level (Poverty Centers in Slovakia) ]. Geografický časopis. 56 (3). 225 - 246

Ministerstvo práce, sociálnych vecí a rodiny Slovenskej republiky [The Ministry of Labour, Social Affairs and Family of the Slovak Republic] (2021). Boj proti chudobe [Fight against poverty] https://www.employment.gov.sk/sk/rodina-socialnapomoc/boj-proti-chudobe/

Ondrejkovič, P. et al., (2009). Sociálna patológia. [Social pathology]. Bratislava : Veda

Pakosta, P., \& Rabušic, L. (2010). Postoje k příčinám chudoby v České republice v letech 1991 až 2008. [Attitudes to the causes of poverty in the Czech Republic from 1991 to 2008]. Sociální studie/Social Studies. 7(4), 101-120

Rabušičová, M., Kamanová, L., \& Pevná, K. (2012). Mezigenerační učení: učit se mezi sebou v rodině. [Intergenerational learning: learning from each other in the family] Studia paedagogica, 17(1), 163-182

Stacey, B. G., \& Singer, M. S. (1985). The perception of poverty and wealth among teenagers. Journal of Adolescence, 8(3), 231-241. doi:10.1016/s0140-1971(85)80055-5 
Strapcová, K. (2004). Sociálne nerovnosti a príčiny chudoby v očiach slovenskej verejnosti. Otázky merania chudoby. [Social inequalities and causes of poverty in the eyes of the Slovak public. Poverty measurement issues]. Bratislava Friedrich Ebert Stiftung, e. V., zastúpenie v Slovenskej republike.

Šipikalová, S. (2014). Nerovnost v príjme a zdraví v krajinách EÚ [The income inequality and health in the european union countries]. Aktuálni Otázky Sociální Politiky : Teorie a Praxe [Current Issues in Social Policy: Theory and Practice], 8(2), 66- 77

Želinský, Z. (2014). Chudoba a deprivácia na Slovensku. Metodologické aspekty a empíria. [Poverty and deprivation in Slovakia. Methodological aspects and empire]. Košice: Equilibria, s. r. o. 